\title{
THE DETERMINATION OF OPTIMAL INVENTORY USING MARKOV CHAIN
}

\author{
Novie \\ Haryadi Sarjono (haryadisarjono@yahoo.com) \\ BINUS University, Jakarta
}

\begin{abstract}
The complication of inventory is a crucial problem for the company because inventory is one of the valuable assets for the company. The existence of inventory control is needed so the inventory levels that exist within the company is not in very large (optimal) therefore the costs incurred by the company can be suppressed as minimum as possible. PT NM is a company engaged in spare parts, especially branded cars in West Jakarta. The level of inventories of goods owned by these companies is high because The company did not want to experience stock out of stock but on one side the stock is large enough so the costs incurred by companies such as storage costs of goods becomes even greater. In order to control inventory levels, this study uses a Markov Chain method that can identify optimal inventory level and the expectation of profits earned per month by making estimates of the future demand a previous demand. From the research results shows expectation of profit of each state starting from state 2 to state 10 is Rp $13.146,98921$; Rp 12.246,94064; Rp 11.346,61466; Rp 10.444,64569; Rp 9.534,074035; Rp 8.584,408534; Rp 7.484,413248; Rp 5.913,288143; Rp 3.211,609986,-. While the profit expectations that earned by the company per month is $\mathrm{Rp} 694.233,333$, and the optimal inventory level is 50 .
\end{abstract}

Keywords: Markov Chain, inventory levels, profit expectation

*) Name of company and product names are disguised as requested

\section{INTRODUCTION}

For the company, the inventory problem is a crucial problem because inventory is one of the most expensive assets in the company, especially in manufacturing company. Inventories reflect $40 \%$ of the total capital invested. The inventories problem is considered important because it's related to the total profit that the company will earn.

Basically, all the company held a planning and controls the goods in aiming to minimize the costs and to maximize the profit in a certain period. The company must maintain inventories so the company operates smoothly. Therefore it is important to have supervision and control over inventories in order to achieve the efficiency in the use of big inventories or small inventories.

One way in controlling inventories in the company is to optimize inventories. Therefore, It is needed a method that can link the current demand and the previous demand which uses Analysis method Markov Chain. Markov Chain was first introduced by Russian Mathematician named Andri A. Markov in 1906-1907. Markov chain is a stochastic process in which current events depend on previous events and only depends at the moment. With the method of Markov chain, companies can find the optimal inventory level by finding the probability of demand at present.

PT NM is one of the companies that engaged in branded spare parts only. The company provides spare parts for commercial cars. The company has significant storage cost. It is because of the amount of inventories in the warehouse is big enough so it is resulting the cost incurred were to be great. The company in operate the inventory system was influenced by the supplier directly and when the company reaches the minimum inventories level (10 


\section{Novie \\ Haryadi Sarjono}

boxes), the company will order the goods in this case, the company inventories so not want to experience stock out but please note the maximum inventory level is also quite high where the customer demand for these goods is not too high. Therefore, to determine the level of inventory, Markov Chain method is appropriate for use because to make an estimate of changes to the future changes to analyze the changes in presence.

The issue discussed in this study is how much profit each state expectations derived from the sale of goods on company, how much profit expectation that was earned by the company per month and how much the optimal inventory levels to the company, whereas the purpose of this research is to know the expectations of profit of each state are derived from the sale of goods on the the company, to know the profit expectation that was earned by the company each month and to know the optimal initial level inventory. The benefits of this research is to enable companies to determine the optimal inventory levels and provide information to companies about the expectations of profits earned by the company.

\section{LITERATURE REVIEW}

\section{Definition of Inventory}

According to Assauri (2008, p237), inventory is an asset which includes the company's property with intent to sell within a period of business or stock of goods that are still under construction or production or supply of raw goods pending their use in a production process. According to Gitosudarmo (2002, p93), inventory is a major component of working capital, an asset which at any time subject to change. According to Zulfikarijah (2005, p4), inventory are stocks of raw materials used to facilitate the production / satisfy consumer demand. Type of supplies includes: raw materials, goods in process and finished goods. It can be concluded from the above that Inventory is an asset and capital owned by a company in the form of raw materials, semi finished and finished material that serves to meet the needs of consumers.

\section{Inventory Costs}

A goal to be achieved in solving inventory problems is to minimize total inventory costs. According Siswanto, (2007, pp 122-123) the costs used in the analysis include:

\section{Ordering Cost}

Costs incurred messages in the event of the booking process of a product. Costs for the manufacture of mail, telephone, fax, and other overhead costs that are proportional to arise because the process of making an order of goods is an example of ordering costs.

\section{Carrying Cost}

Carrying Cost arise in the event the storage of goods. Warehouse rental insurance premiums, security costs, and other overhead costs that are relevant or arising from the storage process is an example of carrying cost. In this case, it was obvious that the charges still appear even though there is no inventory holding cost is not included.

3. Stockout Cost

Stockout costs arise when supply runs out or not available. It is included this cost category are losses due to the engine stops, or the employee does not work. Stock cost lost opportunity to earn profit.

4. Purchase Cost

Purchase costs incurred at the time of purchase of a product. In simple terms the costs are included in this category are those costs that must be paid at the time of paying the purchase of inventory. 


\section{Demand}

According to Kunawangsih and Pracoyo (2006, p29), demand is a different quantity of goods requested by consumers at various prices at a certain period. Meanwhile, according toYoeti (2008, P1 10), demand is defined as one's desire (consumers) on certain goods needed or wanted. There are basically two types of demand that is independent demand (free) and demand dependent (dependent / not free). Dependent demand triggered by specific events, while Independent demand is still fixed.

\section{Markov Chain}

Markov Chain is a random process where all the future information included in the current condition (so there's no need to check the past to determine the future condition). To be more precise, the process has the Markov property which means that the shape of the future only depends on the circumstances now, and not relies on previous form. In other words, a picture of the situation fully captures all the information that can influence the future of the evolutionary process. A Markov Chain is a stochastic process means that all transitions are the probability (it is determined by the random change and thus cannot be predicted in detail, though it perhaps predictable in a statistical nature (http://wartawarga.gunadarma.ac.id/2009/n/markov-chain/).

According to Render, et al. (2003, p646), Markov analysis is a technique related to probability in the future by analyzing the current probability. According to Barry Render, et. al. (2003, p646), there are 4 assumptions in Markov Analysis, which are;

a. The existence of limited point from every possible state where the amount of transition probability from the initial condition system is equal to 1 .

b. The probability change in state is constant over time.

c. It can be predicted in every state in the future by analyzing current state using transition probability matrix.

d. The size of system of or the total amounts of customers does not change during the analysis.

\section{State and Probability State}

According to Render, et al. (2003, p646), state is usually being used to identify all the possible condition from a process or system. In Markov analysis, it is assumed that state has two characteristics:

1) Collective Exhaustive: the researcher can make a list of all state that may appear and it is owned by a system or a process where it is assumed there are a limited number of states for the system.

2) Mutually Exclusive: a system is only on one state at a time (the system could not be in one state).

\section{District Time Markov Chain}

District time Markov chain or known as the discrete time Markov Chain is a Markov chain which has discrete time parameter. In discrete time Markov Chain, there are several kinds of states that are connected to one another. Discrete time Markov chain is a process Markov,

$X_{n}$, that has limited state $a_{i}$, It is characterized in the probability state :

$$
\begin{aligned}
& P i(n)=P\left\{X_{n}=a_{i}\right\} \quad i=1,2, \ldots \ldots \\
& \text { Dan probabilitas transisi : } \\
& \Pi_{i j}\left(n_{1}, n_{2}\right)=P\left\{X_{n 2}=a_{j} \mid X_{n 1}=a_{i}\right\}
\end{aligned}
$$




\section{Matrix Occupancy Time}

Occupancy Time is time expectation (the length of time needed by DTMC (Discrete Time Markov Chain) in specific state (j) during a certain time interval $([0, T])$ that starts from state i. The Calculation of occupancy matrix time always started $n$ when the system has not started moving or when $t=0$. An example is the length of time that can work optimally for a month.

\section{Matrix Probability Transition}

According to Siswanto (2008, p253-254), dynamic variable that has been observed influenced each occurrence in Markov Process is poured into a matrix known as the transitional probability that have the dimension of $m \times n$. In this case, $p_{i j}$ reflects the possible change from state $i$ to state $j$ or from state $j$ to state $i$, depending on the placement, from $i$ and $\mathrm{j}$ or the other way around.

\section{MODEL FORMULATION}

\section{State Determination}

According to Apriani (2006, p102), State determination obtained from the calculation as follows ;

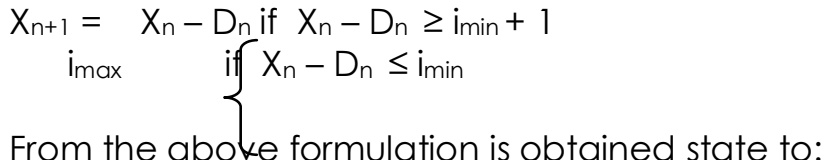

$\left\{X_{n}, n \geq 0\right\}=i_{\min }+1, i_{\min }+2, \ldots, i_{\max }$

Where:

$X_{n} \quad$ : the amount of inventory in the early period of the $n$

$D_{n} \quad$ : the amount of inventory during the period of the $n$

imin : : the amount of minimum inventory that can be order

$i_{\max } \quad:$ the amount of maximum inventory

\section{Determination of Distribution Demand}

Determination of the type of demand was aimed to know the demand of product pattern so it can be determined the probability for all state.

\section{Formation of Transition Probability Matrix}

According to Apriani (2006, p102), to count transition probability of the goods, it can be obtained from the calculation of the below equation:

$$
P_{k}=\frac{e^{-\lambda} x \lambda^{k}}{k !}
$$

Where:

$P_{k} \quad$ : The probability when $k$

e $\quad$ : Euler numbers or Napier constants which its absolute value of 2.71828

$\lambda \quad:$ : The mean of the demand product

k $\quad$ : Interval Demand $(k=0,1,2, \ldots, n)$ 
As for the formation of the transition probability matrix, it is calculated as follows:

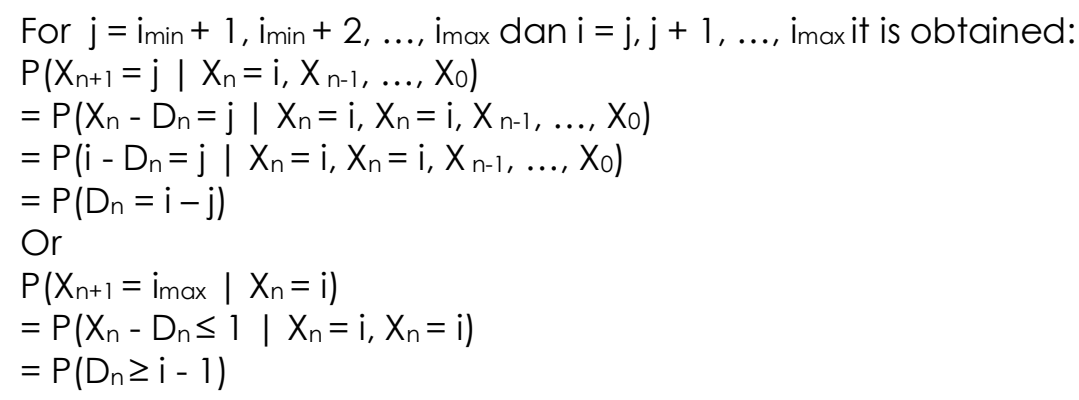

\section{Analysis of Matrix Formation Occupancy Times}

According to Apriani (2006, p 103), to count Matrix Occupancy time, it can use the following formula:

$$
\begin{aligned}
& M(n)=\sum_{r=0}^{n} \operatorname{Pr} \\
& \text { Where } \\
& M(n) \quad: \text { Matrix occupancy time on evaluation period } \\
& P \quad: \text { Transition Probability } \\
& n \quad: \text { Evaluation Period }
\end{aligned}
$$

\section{Determination Profit Expectation Model Each Period}

According to Apriani $(2006,103)$, to determine profit expectation cost, it can be obtained from the calculation as follows:

$$
\begin{aligned}
& C(i)=-H(i)+(H j-H b) E\left(\min \left(i, D_{n}\right) \sum P\left(D_{n}>k\right)\right. \\
& \text { Where: } \\
& \mathrm{H} \quad \text { : Cost Savings } \\
& \mathrm{Hj} \quad \text { : selling price } \\
& \mathrm{Hb} \quad \text { : purchase price } \\
& \text { i } \quad \text { : state of } \mathrm{i} \\
& E\left(\min \left(i, D_{n}\right) \quad \text { : selling expectation of period } n\right. \\
& \text { Whereas the formula of selling expectation on period } n \text { is } \\
& \text { i-1 } \\
& E\left(\min \left(i, D_{n}\right)=\sum_{k=0} P\left(D_{n}>k\right)=P_{k}=\frac{e^{-\lambda} x \lambda^{k}}{k !}\right.
\end{aligned}
$$

\section{Determination of Profit Expectation Model for Each Evaluation Period}

According to Apriani $(2006,103)$, to find profit expectation for each evaluation period by using the calculation as follows:

$$
g(n)=M(n) \times C
$$


Novie

Haryadi Sarjono

RESULTS AND DISCUSSION

\section{Linear Data of Demand}

The following table is the data of linear demand of Commerce Car in March of 2010

Table 1 The Liner Demand of Commerce Car in March of 2010

\begin{tabular}{|c|c|c|c|c|}
\hline Date & Day & Period & $\begin{array}{c}\text { Demand } \\
\text { (boxes) }\end{array}$ & $\begin{array}{l}\text { The Number of } \\
\text { Demand per period } \\
\text { (boxes) }\end{array}$ \\
\hline 1 & Monday & & 6 & \\
\hline 2 & Tuesday & & 4 & 13 \\
\hline 3 & Wednesday & & 3 & \\
\hline 4 & Thursday & \multirow{4}{*}{ I } & 4 & \multirow{4}{*}{15} \\
\hline 5 & Friday & & 7 & \\
\hline 6 & Saturday & & 4 & \\
\hline 7 & Sunday & & 0 & \\
\hline 8 & Monday & \multirow{3}{*}{ ॥ } & 4 & \multirow{3}{*}{11} \\
\hline 9 & Tuesday & & 2 & \\
\hline 10 & Wednesday & & 5 & \\
\hline 11 & Thursday & \multirow{4}{*}{ III } & 6 & \multirow[t]{4}{*}{17} \\
\hline 12 & Friday & & 7 & \\
\hline 13 & Saturday & & 4 & \\
\hline 14 & Sudnay & & 0 & \\
\hline 15 & Monday & \multirow{3}{*}{ IV } & 9 & \multirow{3}{*}{16} \\
\hline 16 & Tuesday & & 6 & \\
\hline 17 & Wednesday & & 1 & \\
\hline 18 & Thursday & \multirow{4}{*}{ V } & 6 & \multirow[t]{4}{*}{19} \\
\hline 19 & Friday & & 10 & \\
\hline 20 & Saturday & & 3 & \\
\hline 21 & Sunday & & 0 & \\
\hline 22 & Monday & \multirow{3}{*}{$\mathrm{VI}$} & 6 & \multirow[t]{3}{*}{15} \\
\hline 23 & Tuesday & & 7 & \\
\hline 24 & Wednesday & & 2 & \\
\hline 25 & Thursday & \multirow{4}{*}{ VII } & 4 & \multirow[t]{4}{*}{12} \\
\hline 26 & Friday & & 5 & \\
\hline 27 & Saturday & & 3 & \\
\hline 28 & Sunday & & 0 & \\
\hline 29 & Monday & \multirow[t]{3}{*}{ VIIII } & 2 & \multirow[t]{3}{*}{14} \\
\hline 30 & Tuesday & & 5 & \\
\hline 31 & Wednesday & & 7 & \\
\hline
\end{tabular}

The table above is the liner demand table for a month (March 2010) where there are 8 periods and each period consists of 3 and 4 days. The division is based on inventory stock checks carried out on Monday and Thursday within a week. The inventory will be order when the inventory is less than 10 boxes.

\section{State Formulation}

The formulation and determination can be seen from the inventory stock of the company. The determination of state using the following formula:

$$
\left\{X_{n}, n \geq 0\right\}=i_{\text {min }}+1, i_{\text {min }}+2, \ldots, i_{\max }
$$


From the data formulation of goods demand within a month, so it obtains a state for initial goods, which are:
1) For State 0 : the amount of initial stock is 2 units (20 boxes)
2) For State $1:$ the amount of initial stock is 3 units
3) For State 2 : the amount of initial stock is 4 units
4) For State 3: the amount of initial stock is 4 units
5) For State 4 : the amount of initial stock is 5 units
6) For State 5 : the amount of initial stock is 6 units
7) For State 6 : the amount of initial stock is 7 units
8) For State 7 : the amount of initial stock is 8 units
9) For State 8 : the amount of initial stock is 9 units

\section{The Determination of Distribution Demand}

After formulating the state, The data of inventory demand per period is processed using SPSS 17 software to determine whether the data of inventory demand is a poisson distribution or non-poisson distribution. The following method is how to test it ;

a. Hypoteses

i. $\mathrm{H}_{0}=$ The data follow the poisson distribution

ii. $\mathrm{H}_{1}=$ The data does not follow the poisson distribution

b. Significance

i. If a (sig) $<0,05$ then The data does not follow the poisson distribution,

ii. If a (sig) > 0,05 then The data follow the poisson distribution

c. Statistic Test

\begin{tabular}{|c|c|c|}
\hline & & $\begin{array}{l}\text { Jumlah } \\
\text { Permintaān }\end{array}$ \\
\hline $\mathrm{N}$ & & 8 \\
\hline Poisson Parameter ${ }^{a . . b}$ & Mean & 14.8750 \\
\hline \multirow[t]{3}{*}{ Most Extreme Differences } & Absolute & .125 \\
\hline & Positive & .118 \\
\hline & Negative & -.125 \\
\hline Kolmogorov-Smirnov $Z$ & & .354 \\
\hline Asymp. Sig. (2-tailed) & & 1.000 \\
\hline
\end{tabular}

d. The result of processing is a (sig) $>0,05$ then The data follow the poisson distribution.

\section{The Formation of Transition Probability Matrix}

Before the formation of transition probability matrix, the data of inventory demand need to be converted. The following data is the data of inventory stock after being converted in unit.

Table 2 Inventory Demand Conversion in Unit

\begin{tabular}{|c|c|c|}
\hline Period & $\begin{array}{c}\text { Demand } \\
\text { (Boxes) }\end{array}$ & $\begin{array}{c}\text { demand } \\
\text { (Unit) }\end{array}$ \\
\hline $\mathrm{I}$ & 15 & 1.5 \\
\hline $\mathrm{II}$ & 11 & 1.1 \\
\hline $\mathrm{III}$ & 17 & 1.7 \\
\hline $\mathrm{IV}$ & 16 & 1.6 \\
\hline $\mathrm{V}$ & 19 & 1.9 \\
\hline $\mathrm{VI}$ & 15 & 1.5 \\
\hline $\mathrm{VII}$ & 12 & 1.2 \\
\hline $\mathrm{VIII}$ & 14 & 1.4 \\
\hline Total & $\mathbf{1 1 9}$ & $\mathbf{1 1 . 9}$ \\
\hline Mean $(\boldsymbol{\lambda})$ & $\mathbf{1 4 . 8 5}$ & $\mathbf{1 . 4 8 7 5}$ \\
\hline
\end{tabular}


The transition probability matrix is determined according to the demand distribution, because the inventory demand distribution on the company is using Poisson distribution, so the calculation of transition probability is using the formula as follows:

$$
P_{k}=\frac{e^{-\lambda} \times \lambda k}{k !}
$$

The calculation of $P_{0}$ and $P_{10}$ :

For $\mathrm{k}=0$, then $\mathrm{P}_{0}$ is :

$$
\underline{P_{0}=} 2,71828^{-1,49} \times 1,490=\mathbf{0 , 2 2 5 3 7 2 8 8 1}
$$

For $k=10$, then $\mathrm{P}_{10}$ is:

$$
P_{10}=\frac{2,71828^{-1,49} \times 1,4910}{10 \times 9 \times 8 \times 7 \times 6 \times 5 \times 4 \times 3 \times 2 \times 1}=0,000003349664477
$$

Table 3 Liner Demand Distribution

\begin{tabular}{|c|c|c|}
\hline $\mathbf{K}$ & $\mathbf{P}\left(\mathbf{D}_{\mathbf{n}} \mathbf{k}\right)$ & $\mathbf{P}\left(\mathbf{D}_{\mathbf{n}} \geq \mathbf{k}\right)$ \\
\hline 0 & 0,225373 & 1 \\
\hline 1 & 0,335806 & 0,774627 \\
\hline 2 & 0,250175 & 0,438821 \\
\hline 3 & 0,124254 & 0,188646 \\
\hline 4 & 0,046284 & 0,064392 \\
\hline 5 & 0,013793 & 0,018108 \\
\hline 6 & 0,003425 & 0,0043152 \\
\hline 7 & 0,000729 & 0,0008902 \\
\hline 8 & 0,000136 & 0,0001612 \\
\hline 9 & 0,0000225 & 0,0001387 \\
\hline 10 & 0,0000033 & 0,0001354 \\
\hline
\end{tabular}

Transition probability matrix describes the transfer of inter-state migration. So the transition probabilities compiled from state 2 to state 10. The Calculation of transition probability matrix elements using the formula:

$P\left(D_{n}=i-j\right)$ atau $P\left(D_{n} \geq i-1\right)$

Here is the calculation of the transition probability matrix element starts from state 2 to state 10:

On the first row, the probability transition is:

$P\left(D_{n}=i-j\right)$ where $i=2$ and $j=2$

$P\left(D_{n}=2-2\right), P_{i j}=P\left(D_{n}=0\right)=0,225373$

$P\left(D_{n} \geq i-1\right)$ where $i=2$

$P\left(D_{n} \geq 2-1\right), P\left(D_{n} \geq 1\right)=0,774627$

After getting the calculation result of transition probability on each row, the results of calculations of transition probabilities of each row can be arranged into matrix form as below: 


$\left(\begin{array}{cccccccccc}2 & 3 & 4 & 5 & & 6 & & 7 & 8 & 9 \\ P\left(D_{n}=0\right) & 0 & 0 & 0 & & 0 & & 0 & 0 & 0 \\ P\left(D_{n}=1\right) & P\left(D_{n}=0\right) & 0 & & 0 & & 0 & & 0 & 0 \\ & P\left(D_{n} \geq 2\right) & & & & & & & & \\ P\left(D_{n}=2\right) & P\left(D_{n}=1\right) & P\left(D_{n}=0\right) & 0 & & 0 & & 0 & 0 & 0 \\ P\left(D_{n}=3\right) & P\left(D_{n}=2\right) & P\left(D_{n}=1\right) & P\left(D_{n}=0\right) & 0 & 0 & 0 & P\left(D_{n} \geq 4\right) \\ P\left(D_{n}=4\right) & P\left(D_{n}=3\right) & P\left(D_{n}=2\right) & P\left(D_{n}=1\right) & P\left(D_{n}=0\right) & 0 & 0 & P\left(D_{n} \geq 5\right) \\ P\left(D_{n}=5\right) & P\left(D_{n}=4\right) & P\left(D_{n}=3\right) & P\left(D_{n}=2\right) & P\left(D_{n}=1\right) & P\left(D_{n}=0\right) & 0 & 0 & P\left(D_{n} \geq 6\right) \\ P\left(D_{n}=6\right) & P\left(D_{n}=5\right) & P\left(D_{n}=4\right) & P\left(D_{n}=3\right) & P\left(D_{n}=2\right) & P\left(D_{n}=1\right) & P\left(D_{n}=0\right) & 0 & P\left(D_{n} \geq 7\right) \\ P\left(D_{n}=7\right) & P\left(D_{n}=6\right) & P\left(D_{n}=5\right) & P\left(D_{n}=4\right) & P\left(D_{n}=3\right) & P\left(D_{n}=2\right) & P\left(D_{n}=1\right) & P\left(D_{n}=0\right) & P\left(D_{n} \geq 8\right) \\ P\left(D_{n}=8\right) & P\left(D_{n}=7\right) & P\left(D_{n}=6\right) & P\left(D_{n}=5\right) & P\left(D_{n}=4\right) & P\left(D_{n}=3\right) & P\left(D_{n}=2\right) & P\left(D_{n}=1\right) & P\left(D_{n}=0\right) P\left(D_{n} \geq 9\right)\end{array}\right.$

\section{The Formation of Matrix Occupancy Times}

Matrix Occupancy Times is a matrix that arranged according to the evaluation period. Matrix Occupancy Times is determined to know the transition probability matrix on the evaluation period. The calculation of Matrix Occupancy Times is always started when the system has not started moving or when $t=0$. The data is processed using software Matchad 14. The calculation matrix occupancy times for $8^{\text {th }}$ period is :

$M(7)=P^{0}+P^{1}+P^{2}+P^{3}+P^{4}+P^{5}+P^{6}+P^{7}$

$$
M(7)=\sum_{r=0}^{7} p^{r}=\left(\begin{array}{ccccccccc}
1.68 & 0.475 & 0.553 & 0.619 & 0.675 & 0.726 & 0.757 & 0.674 & 1.843 \\
0.876 & 1.693 & 0.486 & 0.562 & 0.628 & 0.685 & 0.716 & 0.636 & 1.718 \\
0.897 & 0.878 & 1.694 & 0.487 & 0.564 & 0.631 & 0.668 & 0.596 & 1.587 \\
0.84 & 0.897 & 0.877 & 1.694 & 0.488 & 0.565 & 0.613 & 0.554 & 1.472 \\
0.777 & 0.84 & 0.897 & 0.877 & 1.695 & 0.489 & 0.549 & 0.507 & 1.37 \\
0.722 & 0.777 & 0.84 & 0.897 & 0.878 & 1.696 & 0.474 & 0.451 & 1.267 \\
0.668 & 0.722 & 0.777 & 0.84 & 0.897 & 0.879 & 1.682 & 0.384 & 1.151 \\
0.609 & 0.668 & 0.721 & 0.777 & 0.84 & 0.898 & 0.867 & 1.602 & 1.017 \\
0.541 & 0.609 & 0.668 & 0.722 & 0.778 & 0.841 & 0.887 & 0.799 & 2.156
\end{array}\right) \text {, }
$$

\section{The Determination of Profit Expectations Models Each State}

In determining the profit expectations model that was obtained by the company, the calculation for the model need data of liner storage costs, selling price and buying price. Here are the costs of storage:

Tabel 4 Storage Costs Every Month

\begin{tabular}{|l|l|}
\hline \multicolumn{1}{|c|}{ Type of Storage Costs } & \multicolumn{1}{c|}{ Cost (Rp) } \\
\hline Electricity Costs and Warehouse Supplies & $\operatorname{Rp~350.000,-}$ \\
\hline Insurance & $\operatorname{Rp~250.000,-}$ \\
\hline Security Costs & $\operatorname{Rp~300.000,-~}$ \\
\hline \multicolumn{1}{|c|}{ Total } & $\operatorname{Rp~900.000,-}$ \\
\hline
\end{tabular}


Novie

Haryadi Sarjono

\section{Storage Cost Per unit $\quad$ Rp 900,-}

The profit expectations model is determined to obtain the profit expectation that was caused by selling. The profit expectation is calculated using the following equation:

$$
\text { i-1 }
$$

$C(i)=-H(i)+(H j-H b) E\left(\min \left(i, D_{n}\right) \sum P\left(D_{n}>k\right)\right.$

$$
k=0
$$

Using the formula above, the profit expectation for state 2 is:

$$
\begin{aligned}
& C(2)=-900(2)+(145.000-135.000) \sum_{k=0}^{P\left(D_{n}>k\right)} \\
& C(2)=-1800+14.500(1,030826842) \\
& C(2)=R p 13.146,98921,-
\end{aligned}
$$

The profit expectation for state 10 is

$$
\begin{aligned}
& C(10)=-900(10)+(145.000-135.000) \\
& \sum P\left(D_{n}>k\right) \\
& k=0 \\
& C(10)=-9000+14.500(0,842179999) \\
& C(10)=\operatorname{Rp~} 3.211,609986,-
\end{aligned}
$$

\section{The Determination of Profit Expectation for each Evaluation Period}

After calculating the profit expectation cost, the next step is to calculate the profit expectation for each evaluation period. The calculation of profit expectation for period 8 is processed using software Mathcad 14.

After determining the profit expectation for period 8, the chart was made to see the optimal initial inventory for each evaluation period. Here is the profit expectation chart of the $8^{\text {th }}$ period:

$G(7)=M(7) \times C$

$G(7)=M(7) \times\left(\begin{array}{c}13146,98921 \\ 12246,94064 \\ 11346,61466 \\ 10444,64569 \\ 9534,074035 \\ 8584,408534 \\ 7484,413248 \\ 5913,288143 \\ 3211,609986\end{array}\right) \quad G(7)=\left(\begin{array}{l}68880 \\ 70140 \\ 71270 \\ 71770 \\ 71710 \\ \\ 67430 \\ 62620\end{array}\right) 69870$




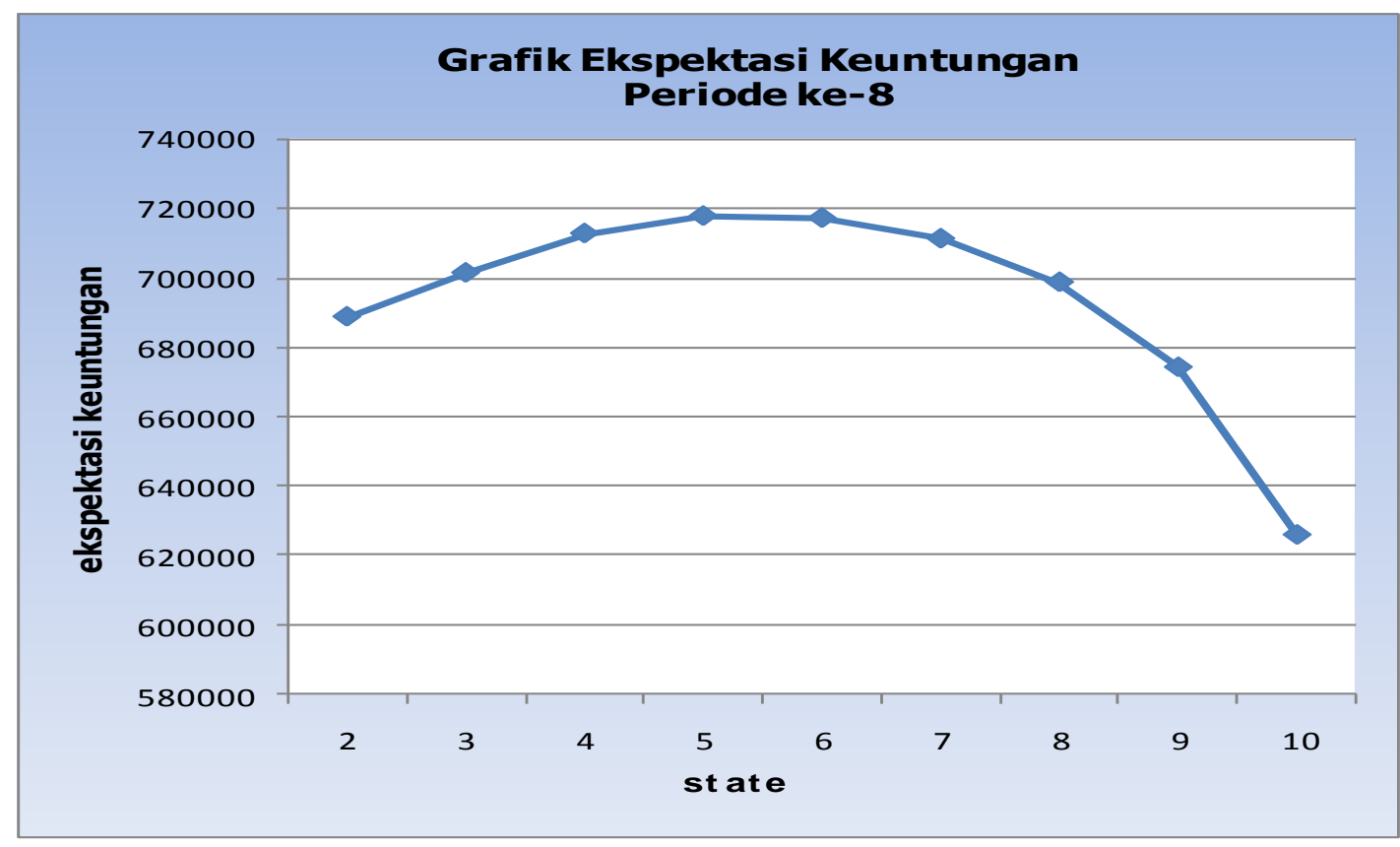

From the graph above, it can be seen that the amount of optimal initial inventory for each evaluation period is 5 units or 50 boxes, where the amount of initial inventory is 5 units or 50 boxes will give maximum profit for each period. The result of processing data can give the level of optimal initial inventory and profit expectation that was obtained. It can be seen on the profit expectation chart where on chart it shows the profit expectation will increase up to certain state which is the optimal initial inventory and then it will decrease when it moves through the level of optimal inventory. So, It can be summarized that the level of optimal inventory is at state 5 where the amount of inventory is 5 units or 50 boxes with profit expectation is Rp 717.700,-.

Because there are 8 periods in a month, the profit expectation that earned by the company each month is:

The average of profit expectation each month:

$=\frac{\operatorname{Rp} 688.800+701.400+712.700+717.700+717.100+711.200+698.700+674.300+626.200}{9}$

$=\operatorname{Rp} 694.233,333,-$

\section{CONCLUSION AND SUGGESTION}

Based on the result of analysis and discussion in this study, about the level of optimal inventory and the company profit expectation for each evaluation period, it can be summarize as it follows:

1. The profit expectation based on the selling for each state tends continue to decrease from state 2 to state 10. For profit expectation state 2 that was earned by the company which is $\mathrm{Rp} \mathrm{13.146,99,-}$ whereas in state 3 is Rp 12.246,94,-. In state 4, the profit expectation that earned by the company becomes Rp $11.346,61,-$. For state 5 , the profit expectation is Rp 10.444,64,-. Where state 6 is Rp 9.534,07,-. In state 7, The value of the profit expectation is $\mathrm{Rp} 8.584,41$,-..For state 8 , the profit expectation is $\mathrm{Rp} 7.484,41,-$. Where state 9 and state 10, the profit expectations continue to decrease which are Rp 5.913,29,and $\operatorname{Rp} 3.211,610$,-

2. The profit expectation foe each month is $\mathrm{Rp} 694.233,333,-$. 


\section{Novie}

\section{Haryadi Sarjono}

3. The level of optimal liner inventory is when the inventory is 50 boxes, it was seen in the chart of profit expectation in period 8 , where at $5^{\text {th }}$ state, the profit expectation was the greatest among others, which is Rp 717.700,--

\section{REFERENCES}

Assauri, Softjan. 2008. Manajemen Produksi dan Operasi. Edisi Revisi. Fakultas Ekonomi Universitas Indonesia, Jakarta.

Gitosudarmo, Indrio. 2002. Manajemen Keuangan. Edisi 4. BPFE, Yogyakarta.

Kunawangsih, T \& Pracoyo, A. 2006. Aspek dasar Ekonomi Mikro. PT Grasindo, Jakarta.

Render, Barry et al. 2003. Quantitative Analysis for Management. 8th Edition. Prentice Hall, New Jersey

Siswanto. 2008. Operation Research Jilid II. Erlangga, Jakarta.

Yoeti, Oka. 2008. Ekonomi Pariwisata. Buku Kompas, Jakarta.

Zulfikarijah. 2005. Manajemen Persediaan. Universitas Muhammadiyah, Malang.

(http://wartawarga.gunadarma.ac.id/2009/n/markov-chain/) 